\title{
Assimilating Indonesia Chinese Muslim in Makassar (1967-1997)
}

\author{
Nurhayati Ahmad \\ Teacher at State Senior High School 15 Makassar, Ir. Sutami Street Number 2, Indonesia \\ taty.sejarah123@gmail.com
}

\begin{tabular}{ccc}
\hline Received & Accepted & Published \\
$11 / 12 / 2017$ & $24 / 03 / 2018$ & $30 / 04 / 2018$ \\
\hline
\end{tabular}

Abstract The ethnic Chinese Muslims in Makassar has been there since the year 1606 in conjunction with Islam in Makassar. Dato ri Bandang was the one who initiated the spread of Islam among Chinese people of Makassar. During the new order, ethnic Chinese Muslims in Makassar city had done the intermingling with local communities. The new order had kept many discriminatory elements contains policy against ethnic Chinese in the city of Makassar. This is the sort of policy that directly affects the life of the field of social, cultural, political and religious. Although they are more successful in the field of economics. Even so, ethnic Chinese Muslims in Makassar when it is capable of performing a merging in all areas of social life.

Keywords: Straits-born Chinese; Muslim; Intermingling; Makassar.

Abstrak Etnis Tionghoa yang Muslim di Makassar telah ada sejak tahun 1606 bersamaan dengan masuknya Islam di Makassar. Dato ri Bandang adalah orang yang mengawali penyebaran dakwah di kalangan orang Tionghoa Makassar. Selama Orde Baru, Etnis Tionghoa Muslim di Kota Makassar telah melakukan pembauran dengan masyarakat setempat. Masa Orde baru telah menyimpan banyak kebijakan yang mengadung unsur diskriminatif terhadap etnis Tionghoa di Kota Makassar. Kebijakan semacam inilah yang langsung berdampak pada kehidupan bidang sosial, budaya, politik dan agama. Walaupun begitu mereka lebih berhasil di bidang ekonomi. Meskipun begitu, etnis tionghoa muslim di Makassar saat itu mampu melakukan pembauran dalam segala bidang kehidupan sosial kemasyarakatan.

Kata kunci: Tionghoa; Muslim; Pembauran; Makassar. 


\section{INTRODUCTION}

Ethnic Chinese in Indonesia have a long enough history to start from since they first came and spread to various parts of Indonesia until now shows that they deserve is considered a valid section. They are a tribe that became a part of Indonesia the nation-State is indeed composed of nations and tribes (Soyomukti, 2012:155). However, the Government wants them from among the ethnic Chinese to live and mingle with the natives of Indonesia (indigenous people). The attitude of this Government looks with the ban of Badan Permusjawaratan Kewarganegaraan Indonesia/BAPERKI (Agency of Deliberations Indonesia Nationality) and other Chinese clubs, the new rulers began construction of Lembaga Pembinaan Kesatuan Bangsa /LPKB (Institutions Supporting the Unity of the Nation) which was commissioned by new order to address the issue of Chinese. The Agency is supported by the Government advocated the Chinese in Indonesia total assimilated into the indigenous population and as the only solution to the problem of Chinese groups. LPKB dissolved in the future until the communication Agency formed in 1977 under the auspices of the Ministry of Internal Affairs which serves as a bridge between the Chinese Government and people (Suryadinata, 1981:1).

This continues until the mingling going on marriage and assimilation among society among ethnic Chinese with the indigenous. In a further development, the Chinese began their mingling with the indigenous communities in the areas of assimilating includes religion be mixed marriages between ethnic Chinese with a native community in the city of Makassar. From the results of his marriage, children and their descendants often refer to as "Makassar Straits Chinese". Muslim Straits Chinese most anyone who first converted to Islam since their ancestors who did the marriage with a Muslim local people so that their posterity still embraced the religion of his ancestors were hereditary and There are also converted to Islam because of the inspiration as well as due to the intermingling of social, cultural and religious, they are after Islam Muslim running consistently.

In the field of economy and trade, in general, the livelihoods of ethnic Chinese Muslims are as traders and entrepreneurs. Although there have been Muslim, they admit that the teachings of their ancestors have given the huge influence on every aspect of life against the Ethnic Chinese. The influence of the inside as well and their economic behaviour. The principles of behavioural economics ethnic Chinese in the city of Makassar indeed always change from time to time, but in general, the principle of economy of ethnic Chinese behaviour always depends on their understanding of policy and the situation of the political conditions in nationwide about the existence of ethnic Chinese. This eventually leads to economic behaviour in the business which is safe and neutral in the political situation nationally in the sense that it does not contain many risks for the safety and welfare of myself. 
Now the boundaries of the separator between ethnic Chinese and other ethnic communities of Indonesia increasingly faded. If Chinese society used to be regarded differently and unfairly treated, now not anymore. Stretching and existence of Chinese society more visible. The nature of exclusivism by the Chinese now have started to open. They are no longer required to rename it so that the smell of Indonesia as applicable the new order, allowed to roll out its original art and culture, such as Lion dance, Chinese New Year also celebrate. Even now with the changes has a lot of Chinese who decide to enter Islam.

The development of Chinese Islamic adherents is growing push Chinese Muslims to erect a mosque h. Muhammad Cheng Ho in the streets of Arupala and in the Tanjung Bunga. The establishment of this mosque aims to be a means of worship for the ethnic Chinese descent and at generally to Makassar city community that exists around it. Mingling conducted by Chinese Muslims in Makassar city has brought an impact on many areas of life, among others, the areas of the social, cultural, economic, political and religious divide among ethnic Chinese Muslims in Makassar city as well as for the public and the Government that is in Makassar.

The nomads who came to Southeast Asia in General and in Makassar on particularly troubled by a variety of factors, which generally can be classified into two major groups, i.e. a factor of economic and political factors. The economic factor is, that the land of China during the Ming dynasty (1368-1644), the population has exploded, while land-agricultural land no longer can guarantee the survival of its inhabitants. This difficulty is compounded by land Lords who raised high land lease so that the livelihood of farmers increasingly difficult, causing them to easily do the migration. In General, the Chinese are there in Makassar consists of several different ethnic and regional. But those in Makassar known or grouped into two major groups namely Chinese full-blooded and Straits-born Chinese. Straits-born Chinese, unlike the fullblooded later immigrated to Makassar. The classification is not based on birth but concerns the question of the degree of adjustment of the acculturation of the Chinese culture against the nomads of Makassar.

The formation of Straits-born Chinese community began when immigrants who come in groups and then settled in Makassar. They are mostly people Hokkien then mate with the local women because women almost no Chinese immigrated. Until the 20th century, the descendants of Noah then formed the Straits-born Chinese community steady, then formed its own group. The House of Straits-born Chinese culture it developed itself, which not only was a mixture of Chinese and indigenous culture but in many elements of life has resembled those of Makassar. The formation of Straits-born Chinese community began when immigrants who come in groups and then settled in Makassar. They are mostly people Hokkien then mate with the local women because women almost no Chinese immigrated. Until the 20th century, the descendants of Noah then formed the Straits-born Chinese community steady, then formed its own group. The House 
of Straits-born Chinese culture it developed itself, which not only was a mixture of Chinese and indigenous culture but in many elements of life has resembled those of Makassar. Although it can still be distinguished from the local population, such as the use of Malay-Chinese language Chinese, Bugis-Makassar-Makassar as the language or languages to be used daily. The straitsborn Chinese community in Makassar is a new community group formed of two ethnic backgrounds between ethnic Chinese with the ethnic Makassar (Bahrum, 2003:127).

Chinese Muslim population experiencing the unpleasant conditions of the Netherlands colonizers because they have a closeness with the natives, they are Muslims like most native religions. Chinese Muslim population also did a resistance against the invaders with the joining fighters Indonesia. Some of this shows that in the past, ethnic Chinese also has a good relationship with the natives of Indonesia, closeness relationship as brothers due to get the same pressure from the Portuguese and Netherlands. Ethnic Chinese immigrant Muslim population accepted Indonesia their role in agriculture, trade, carpentry, and the spread of Islam.

Persatuan Islam Tionghoa Indonesia/PITI (Islamic Union of Chinese) is one manifestation of the presence of ethnic Chinese Muslims, particularly in the city of Makassar. When viewed from the historical roots of his birth, PITI is an organization of containers of Chinese Muslim community from all over the country. The Organization has a goal to unite the Muslims of Chinese in Indonesia in one container, so it was more instrumental in unifying the nation. As for some of the Chinese Muslim figures who joined in the formation of the PITI is Haji Yap Siong who hails from the town of Moyen, China. He became a Muslim in 1931 and founded the Islamic propagation organization with the name of the Chinese Islamic Union (PIT) in the town of Deli Serdang, North Sumatra. He began preaching from North Sumatra to South Sumatra and crossed towards West Java to East Java. In preaching the Yap Siong Hajj using Mandarin, she obtained the permission of the spread of Islam from Netherlands Colonial officials (Arief, 1994: 3)

Intermingling is a social process that arises when there are: 1) the human factions with differing cultural backgrounds; 2) directly associating each other intensively for a relatively long period of time; 3) cultures of the groups above each changed each other adjust to being a cultural mix. Usually, the intermingling between the majority and the minority, while the minority groups adjust to the majority (Koentjaraningrat, 1980:126). The problem of intermingling in daily life is still a problem. This will not occur if the previous principals of good assimilation of minorities, as well as majorities, understand properly what is the soul of assimilation, which means that there should be a strong foundation built above a merging of forms, so there is nothing sacrificed her feelings from one party (Haryono, P., 1994:14). 
The intermingling of many dimensions of life concerns turned out to be. As the knowledge can be quoted from Milton Gordon, a sociologist from the United States. He has elaborated on the concept of intermingling as a social process involving either minority or majority groups in seven kinds of intermingling of relating to each other, namely: 1) intermingling of culture (or opened) are associated with changes in patterns of culture to conformity with the majority; 2) structural borne Intermingling with the entry of the major minority groups in groups, clubs and institution-institution on the level of the primary group of the majority; 3) Intermingling marriage related to interracial marriage the massively; 4) Intermingling identification associated with the development of a sense of nationhood based on majority; 5) Intermingling attitudes related to no existence of prejudice; 7) merging of behavior that is not associated with the presence of discrimination; 8) Intermingling "civic" is not related to the presence of a clash on the system of values and sense of power (Haryono P, 1994:12-13).

Departing from the above problems, feel important for the writer to explore about the Intermingling of Chinese Muslims in Makassar city. Writing this review about the living conditions of Chinese Muslims in the Central Government's policy discriminatory and assimilative. Aspects described Chinese Muslims include the background to the emergence of the Chinese Muslim community in the city of Makassar, the intermingling of Chinese Muslims in Makassar city and the impact the presence of the Chinese Muslims were taking action against social life, economics, politics, culture and religion in the city of Makassar.

\section{METHOD}

The methods used in this paper that are by using the methodology of history which include heuristics, critical source, interpretations and historiography. A heuristic is an early stage to collect all the historical data of the existing connection with this writing. The steps are done in the collection of data, namely work directly contributes by doing an interview or interviews with the actors and witnesses of history, looking for materials research support in the form of such a book in the library and others. After the data is collected, the next step is to do a good source of criticism is a criticism of internal and external criticism so that all data can be verified. Data interpretation should be verified for turn on and explain the data to then do historiography. The writing of history to the point of climax in historical methodology.

\section{RESULT AND DISCUSSION}

\section{The Influx of Chinese Muslims in Makassar}

Regarding the arrival of the Chinese people in Indonesia, until now it has not been in the know for sure when they first land in Indonesia. But from some book that describes the arrival of Chinese in Indonesia for the first time said that the Chinese come in long before the 
archipelago centuries start, there also said that the arrival of China in the archipelago in the early first century and some are saying that the Chinese are coming in the archipelago at the time of the Tang dynasty to power coincided with the purpose of his advent IX century that is to trade and seek new life (Sitabuana, 2014:41). While the history of the presence of ethnic Chinese Muslims in Indonesia began when the existence of the voyage of Admiral Zheng He of the Ming dynasty. She waded through a sea of visiting some countries in Southeast Asia, and other regions including East Africa. Cheng Ho with a lead of about 27 thousand ships sail the seas of the visit included the archipelago cruise on seven times in the year 1431. Since Cheng Ho cruise the 6th fought in 1421-1422 and at the time Xuan De hasn't boarded the thrones (From, 2000:73).

The influx of ethnic Chinese in Makassar of South Sulawesi and a part that is inseparable from the arrival of the Chinese people in the archipelago. According to Sulaiman alias Tjia Goam Lien stated that the arrival of the ethnic Chinese in South Sulawesi began when Chinese tribe who came from Java and Kalimantan using boats made of wood and based on screen from bamboo leaves (Sulaiman, 1953:24). They come in stages, originally only come to trade, but gradually began to settle mainly in the coastal shoreline. The Chinese community is beginning to play an important role in Makassar in 1618, they officially open its trade representative office in Makassar (Poelinggomang, 2002:28). Since its presence in the Makassar for commercial lanes of Nusantara at that time, the ethnic Chinese have played the role of politics and economy and trade dynamics and full of ups and downs.

However, during the reign of the colonial Netherlands, occurred the separation between indigenous people with indigenous people. The Government does not want to confound Indonesia society with people of Europe (particularly the Netherlands) and ethnic Chinese. From that policy, ethnic Chinese in Chinese social strata are in the second position after the Europeans and natives are at the lowest strata. Chinese ethnic groups existing in Indonesia is regarded as a separate group of natives because they include other races and not part of the country (Suryadinata in Abdullah, et al, 2012:451).

This policy is to maintain the position of the colonial Government at the time, But after Indonesia became independent, the system of social strata in Indonesia to change. Now the natives are the top in the new social strata while indigenous people occupied the lower strata. Government policies often reflect this situation (Suryadinata in Abdullah, et al, 2012:452), one of which, namely about the policy of assimilation and integration. Nevertheless, the concept of integration according to BAPERKI that Indonesia ethnic Chinese should be accepted as a tribal group like other tribes that existed in Indonesia, can stand with parallel, recognized and accepted as a fact, as well as get fair treatment and equal to citizens. Thus the identity as an ethnic Chinese still can be maintained in the nation of Indonesia (Sitabuana, 2014:85). 
Different style when new order "regime" was in power, Chinese Ethnic Chinese Muslims in general or in particular are having a very difficult time, the trauma of movement 30 . S who consider PKI as the culprit (G. 30. S/PKI), made during the new order Government began limiting the space they are mainly in the field of politics and culture. They were only given room to thrive in the economic and trade field alone. Such policies make them add more exclusive in excessive suspicion in the new order era against the Chinese people in Indonesia are in value as part of the Partai Komunis Indonesia/PKI (The Communist Party of Indonesia).

\section{The Intermingling of Chinese Muslims in Makassar}

Leo Suryadinata in his book entitled ethnic Chinese and nation-building to mention that Government policy has been quite successful in the sense that a lot more full-blooded Chinese become more Chinese and becomes more Indonesian. However, most Chinese ethnic groups remain unresolved. In the form of culture, Chinese people have become more Indonesia. But the categorization between groups remains plainly (Suryadinata, 2010:187). It must be admitted that so far there is the impression that there is still an attitude not happy and discriminating against the ethnic Chinese in Indonesia. In addition to that, there is also a tendency to defend indigenous communities over the part on the one hand, and non-natives in the other hand. So also in the world of Chinese politics, society seemed less have a place if compared with (Tarmizi Taher (1997) and Leo Suryadinata (2002) from the Indonesia other ethnic communities.

Looking at the State of ethnic Chinese like that then this real ethnic Chinese, constitute heterogeneous community groups which each have different cultural orientation. If viewed from the historical origins of his return, ethnic Chinese can be divided into two groups, namely the Straits-born Chinese and full-blooded Chinese (Suryadinata, 2002:17-18). Straits-born Chinese is a society of Chinese descent who have been long in a matter of a couple of generations living and make a living in Indonesia and already experience assimilation with the community on the environment. In terms of the languages they have become accustomed to using the language of Indonesia, or even language area they live in, as the everyday language, both inside the House and outside the House. They generally also behave like other ethnic groups, as well as its already-oriented culture of Indonesia.

While is a full-blooded Chinese are those who generally just entered or came to Indonesia a generation or two. They usually also referred to as "singke" meaning. They are generally still embraced the culture and customs of the Chinese, and to communicate with each other still use their native language, in this case of course Chinese. Seen from the existence of the ethnic Chinese community categorization into two groups (Straits-born and full-blooded Chinese), then the existing ethnic Chinese in Indonesia is actually a minority group that is heterogeneous (Suryadinata, 2002:17-18) 
Chinese people living in Makassar, consciously or not, are also affected by the setting and the cultural values of the ethnic Makassar and surrounding areas. If the background and influence of the cultural values of the ethnic Makassar and surrounding areas were pervasive in the mindset and behaviour of Chinese people, both from among the Straits-born Chinese or fullblooded Chinese, it is an inevitability. How not, already umpteen hundred years and the generation of ethnic Chinese covered by and interact with those tribes as well as Makassar in South Sulawesi (Bugis, Toraja, Mandar, etc.) who lives settled or working while in Makassar. This is the kind of action that gave rise to the term Chinese, Bugis, Makassar, Chinese Chinese Chinese Toraja, Mandar and others, which can be genealogies, cultural nuances or a combination of both.

\section{The impact of Chinese Muslims in Makassar Intermingling}

Chinese in Indonesia generally admits to confusion to choose, whether to maintain the Straits-born Chinese of them or have to leave at all all of their ancestors and are fully fused to in the majority of the community. On the one hand, they feel that as citizens in the midst of the nation's actual multi this ethnic, cultural and political rights they have been challenged. But on the other hand, they are proud as Chinese people, among others, due to their high economic status, even if they do not feel protected from the majority group of aggressiveness at times can arise. ,

From the above, it can be seen that they were actually strong, for a variety of pressures or marginalize them shrink responded with great struggle so that they look more and more powerful and do not feel marginalized. Where should they be given in recognition of his achievements and since ancient times, and given the opportunity to develop all that they have together and side by side with other ethnic origins do not lead to exclusive and conservative. Things that need to be eliminated is the view stereotype against them and vice versa, which certainly is not conducive to the present and potentially trigger social conflict.

In the context of the diversity of Chinese Muslims in Makassar, ethics social ethics is inseparable from religion. This is for example demonstrated the readiness of the members of the Islamic studies activities to alternately contribute in financing activities. Similarly, their readiness to sacrifice financially over the construction of the two mosques that are pleasantly luxurious Hoo Cheng in Gowa Makassar and territory into other indicators for the integration of Chinese social ethics with Islamic Ethics (Rosmini, et al 2016:94). Every Lunar New Year in Makassar, the general public who are not ethnic Chinese can leave entry to temples or monasteries are even though they are not religious Confucianism or Buddhism. The public can watch the procession of the praying activity of Confucianism through the temple doors wide open. Religious openness attitude like this do the people of Chinese Confucianism as a form of 
statement to the public that they do not need to hide because they are not suspected of anything.

A number of traditions in practice and is followed by the Chinese Muslim Makassarese, though no longer constrained by the strict rules of that tradition. On the day of Chinese new year, food served is not meant to believe the myths as it is believed other Chinese. However, the above tradition more positioned as the momentum for a big family gets together sometimes composed of adherents of different religions. These facts certainly require adaptations themselves a Muslim so as not to make Islam into the cause of the occurrence of the cracks had the relationship with family size. It's also why, attitudes to diversity in pluralistic of Islam as a part of Chinese Muslims are not unbiased in avoid (Rosmini, et al 2016:104).

The phenomenon of tolerant diversity as one of the indicators of the moderation of religion that is practised by Muslims of Chinese Makassar development phenomena is one of the mosques of Muhammad Cheng Hoo mosque, that is located on Tun Razak Hertasning Street. Construction of the mosque donation not only comes from donations the Muslims, particularly Muslim Chinese, but the completion of the construction of this mosque is inseparable from the contribution of several Chinese non-Muslims who voluntarily contributes financially in the construction of the mosque of Muhammad Cheng Hoo. Recognized that it is extremely sensitive in Muslim discourse of Islamic Chinese, but still make sure that the property earned by Chinese non-Muslims which were then donated to the construction of the mosque of Muhammad Cheng Hoo is private property rights and acquired in ways that are lawful, even if the owner is not a Muslim.

Diversity facts above reveals the existence of an attitude of tolerance in religion that is owned by a Chinese Muslim. Another form of religious tolerance of Chinese people is shown by one of the Chinese Muslims in Makassar. According to her religious tolerance should be kept to a minimum as possible and should not be entered in the contact area of belief (Rosmini, et al 2016:106). One of the impacts of Chinese Muslims keeps intermingling strives to maintain a tolerance between the beliefs of other Chinese communities with different beliefs with them. Although sometimes celebrates Chinese new year feast made by Chinese non-Muslims, but not necessarily join believes its ritual, as an attempt to keep harmony in the diversity of beliefs.

Diversity is not seen as a differentiator to not respect and appreciate one another. However, diversity can be attempted to create a harmonious life with colourful upholds the values tolerance. Mutually help each other between religious shown by Chinese Muslims and so also by other faiths in Makassar city can become an embryo for the establishment of a good relationship with all the while respecting difference. As Chinese new year events such as Chinese new year celebrations, even though in the teachings of Confucianism and Buddhism are 
considered part of the religious tradition, but for Chinese Muslims of Chinese existence, Makassar reconstructed became part of the cultural tradition, not of tradition religious (Rosmini, et al 2016:107).

\section{CONCLUSION}

Based on the previous discussion, it can be inferred that the Chinese people that came in Makassar from different ethnic and cultural backgrounds who have different. Dato ri Bandang was the one who initiated the spread of Dawah among Chinese people of Makassar. This is where the early history of the point of entry of the religion of Islam among Chinese people of Makassar. One by one the Chinese abandoned his religion and began turning to Islam. Until now the ethnic Chinese Muslims in Makassar city grew along with the presence of acculturation and assimilation of the two local culture.

Ethnic Chinese Muslims in Makassar on the new order has been doing intermingling with the local community as a business and a continuation of the policy of the Government to undertake a total assimilation. But those efforts until now have not led to results that can be used as a foothold for all parties over this issue. It must be admitted that there is still some confusion over this attitude displeased and discriminating against the ethnic Chinese in Indonesia. So also in the world of Chinese politics, society seems to have a place less when compared to other ethnic communities from Indonesia. While at the same time we know that the people of Chinese descent thus greatly excelled in the fields of economy, so often they become targets of social jealousy.

During the new order, the ethnic Chinese in the city of Makassar has felt the direct impact in the public eye because of government policies that are likely to be discriminatory. In the social and cultural field, they often get a race discrimination and the problem of state status. They also restricted the movements and actions in the world of politics. While in the area of religion, under certain conditions they are required to choose a particular religion. In conditions as well as limited as it is, they don't have other options, in addition to the economic world to trade, become entrepreneurs and plunge into the world of business. The end result is a lot of them become a successful entrepreneur and become advocates of economic power in the city of Makassar.

\section{REFERENCES}

Abbas, Irwan. 2007. Awal Islamisasi dan Kristenisasi di Timur Nusantara. Makalah disajikan dalam Seminar Empat Abad Islam Melembaga di Sulawesi Selatan. Makassar: Seminar dilaksanakan di Unhas 5-7 September 2007.

Abdullah, Hamid. 1991. Manusia Bugis Makassar. Jakarta: Inti Idayu Press. 
Al Qurtuby, Sumanto. 2003. Arus Cina Islam Jawa. Bongkar Sejarah atas Peranan Tionghoa dalam Penyebaran Agama Islam di Nusantara Abad XV \& XVI. Jakarta: Inspeal Ahimsyakarta Press.

Arief, Khozyn. 1994. Sejarah dan Perkembangan PITI Kiprah PITI di Gelanggang Nasional. Makalah Dalam Seminar dan Musyawarah Wilayah PITI DIY.

Bahrum, Shaifudin. 2003. Cina Peranakan Makassar: Pembauaran Melalui Perkawinan Antar Budaya. Makassar: Yayasan Baruga Nusantara.

Bahrum, Shaifudin. 2006. Kumpulan Sajak (kelong) Makassar. Ho Eng Dji, Bunga Sibollo.. Makassar: Yayasan Baruga Nusantara

Bahrum, Shaifudin. 2008. Berubah: Metamorfosis masyarakat Tionghoa Makassar dalam 10 tahun Reformasi. Makassar: Yayasan Baruga Nusantara.

Gani, Joice. 1990. Cina Makassar: Suatu Kajian Tentang Masyarakat Cina di Indonesia 1906-1959. Ujung Pandang. Skripsi Jurusan Sejarah FS Unhas.

Haryono, P. 1994. Kultur Cina dan Jawa (Pemahaman Menuju Asimilasi Kultural). Jakarta: Pustaka Sinar Harapan

Heriyanto, Ariel. 1999. "Rape, Race and Reporting" dalam Arief Budiman, Barbara Hatley dan Damien Kingsbury (eds), Refeormasi: Crisis and Change in Indonesia. Clayton: Monash Asia Institut.

Hoon, Chang-Yau. 2012. Identitas Tionghoa: Pasca-Soeharto, Budaya, Politik dan Media. Penerjemah, Budiawan. Jakarta: Yayasan Nabil dengan LP3ES.

Jahja, Junus. 2005. Sang Pemula Karim Oei Nasionalis Indonesia, Muslim Taat dan Pengusaha Sukses. Jakarta: Yayasan Haji Karim Oei.

Karim, Abdul. 1982. Mengabdi Agama Nusa dan Bangsa. Jakarta: PT Gunung Agung

Koentjaraningrat. 1964. Pengantar Antropologi. Jakarta: UI.

Koentjaraningrat, 1980. Manusia dan Kebudayaan di Indonesia. Jakarta: Djambatan.

Lien, Tjia Goam. 1953. Asal Usul Tionghoa Islam di Makassar. Mimbar Agama. 3 Maret tahun keempat.

Polinggomang, Edwar L. 2002. Makassar Abad XIX: Studi Tentang Kebijakan Perdagangan Maritim. Jakarta: Kepustakaan Populer Gramedia.

Rosmini, dkk. 2016. Geliat Keberagamaan Moderat Komunitas Muslim Tionghoa: (Studi Kontribusi Pengkajian IslamIntensif dalam Keberagamaan Moderat Muslim Tionghoa Kota Makassar). Makassar: PKBM rumah buku carabaca.

Sitabuana, Tundjung H. 2014. Penyelesaian Masalah Diskriminasi Terhadap Etnis Cina: Studi Tentang Perkembangan Politik Hukum di Bidang Kewarganegaraan Republik Indonesia. Jakarta: Konpress

Soekanto, Soerjono. 2012. Sosiologi Suatu Pengantar. Jakarta: Rajawali Pers

Soyomukti, Nurani. 2012. Soekarno \& Cina. Jogjakarta: Garasi.

Suryadinata, Leo. 1992. Peranakan's Search for National Identity, Marshal Cawendish Academik 
Suryadinata, Leo.2007. Laksamana Cheng Ho dan Asia Tenggara. LP3IS.

Suryadinata, Leo. 2012. Peran Kelompok Etnik Tionghoa dan Kebijakan Negara dalam Abdullah, Taufik dkk. 2012. Indonesia dalam Arus Sejarah: Orde Baru dan Reformasi, Jilid 8. Jakarta: PT. Ichtiar Baru van Hoeve.

Suryadinata, Leo. 1978. Pribumi Indonesians, the Chinese minority and China: A Study of Perceptions and Politics. Singapore: Heinemann Educational Books.

Suryadinata, Leo. 1981. Political Thinking of the Chinese Minority in Indonesia. Singapore. Singapore University Press.

Suryadinata, Leo.1999. Etnis Tionghoa dan Pembangunan Bangsa. Jakarta: Pustaka LP3ES.

Suryadinata, Leo. 2002. "Negara dan Minoritas Tionghoa di Indonesia". Lampiran dalam Leo Suryadinata (Penyunting Widjanrko). Negara dan Etnis Tionghoa: Kasus Indonesia. Jakarta: Pustaka LP3ES Indonesia.

Yuanzhi, Kong. 2000. Muslim Tionghoa Cheng Ho: Misteri Perjalanan Muhibah di Nusantara. Jakarta: Pustaka Populer Obor.

Zein Baqir, Abdul. 2000. Etnis Cina dalam Potret Pembauran di Indonesia. Jakarta: PT. Prestasi. 